\title{
What is Intermediate Legislative Power?
}

\section{Shubhankar Dam, University of Portsmouth}

The president in India's parliamentary system is authorized to promulgate legislation under Article 123. ${ }^{1}$ While such legislation, or "ordinances," enjoy the same force and effect as Acts, they are distinct in some ways. First, ordinances lack legislative deliberation: the president promulgates them "except when both Houses of Parliament are in session.” Second, it depends on the president's satisfaction that “circumstances exist that render it necessary for him to take immediate action.” And they are transient: ordinances cease to operate on the expiry of six weeks from the reassembly of parliament unless withdrawn earlier or formally enacted into law. Ordinances, then, are typical cases of executive legislation. Authored by the Council of Ministers to the exclusion of parliament and discretionarily promulgated into effect by the president, they are products of a parallel - and exceptional - power to legislate.

This article is about the judicial review of presidential satisfaction in Article 123. When a president, for whatever reason, promulgates an ordinance into law, is to open to the courts to review that assessment? Consider a parliamentary analogy. When parliament enacts legislation, courts, in India and elsewhere, frequently review their constitutionality. But parliament's assessment that a law is needed is generally considered outside the scope of judicial review. ${ }^{2}$ On that, courts express no opinion. With ordinances, the president partially morphs into parliament. Should courts, then, review presidential satisfaction that “circumstances exist that make it necessary ... to take immediate action”?

In addressing that question, I will begin by arguing that syllogistic reference to presidential satisfaction in other provisions of the Constitution - a common starting point - is conceptually unhelpful. Thereafter, I will identify three argumentative strategies through which judicial review may be interpreted, and in the process introduce the concept of an “intermediate” legislative power - a category that is neither fully executive, nor fully legislative, but with important components of both. In the rest of the article, I will explain the implications of this concept, while examining how Indian decisions have either rejected or impliedly relied on it in addressing the question of judicial review.

\footnotetext{
${ }^{1}$ See Shubhankar Dam, 'Constitutional Fiats: Presidential Legislation in India’s Parliamentary Democracy' 24(1) Columbia Journal of Asian Law 91 (2010); D. C. Wadhwa, Re-promulgation of Ordinances: A Fraud on the Constitution of India (Gokhale Institute of Politics and Economics 1983); D. C. Wadhwa, Endangered Constitutionalism: Documents from a Supreme Court Case (Gokhale Institute of Politics and Economics 2008). ${ }^{2}$ See State of AP v. McDowell \& Co. AIR 1996 SC 1627; Nayar v. Union of India AIR 2006 SC 3127.
} 


\section{Presidential Satisfaction in Article 356: A False Start?}

It is common to begin discussions on the reviewability of presidential satisfaction in Article 123 with references to Article 356 in India’s Constitution. That provision says that "If the President ... is satisfied that a situation has arisen in which the Government of the State cannot be carried on in accordance with the provisions of this Constitution ...," she may make a Proclamation to that effect. Such proclamations have a debilitating effect on states for the president may assume "all or any of the functions of the Government of the State ...;”3 "declare that the powers of the Legislature of the State shall be exercisable by ... Parliament" and "make such incidental ... provisions ... including provisions for suspending in whole or in part the operation of any provisions of [the] Constitution ...” ${ }^{5}$ The Supreme Court in Bommai $v$ Union of India, ${ }^{6}$ partly reversing its earlier decision in State of Rajasthan $v$ Union of India, ${ }^{7}$ concluded that the president's satisfaction in Article 356 is judicially reviewable.

A bench of nine judges produced six separate or joint opinions running into 700-odd pages. While they disagreed on the appropriate scope of judicial review, they were all in agreement on the basic question of judicial review. A "personal whim, wish, view or opinion" is insufficient; a president's satisfaction has to be based on "a legitimate inference drawn from the material ... relevant for the purpose,” the Court said. ${ }^{8}$ And there must be "sufficient proof of information with regard to... the state of things indicating that the situation in question has arisen."9 This view was reiterated in Prasad v Union of India another instance where presidential satisfaction in Article 356 was challenged on the grounds of extraneous considerations. ${ }^{10}$ Chief Justice Sabharwal concluded that the president's satisfaction "can be challenged on the ground that it is mala fide or based on wholly extraneous and irrelevant ground." ${ }^{11}$ While courts would not attribute bad faith or motive to the president lightly, it may be invalidated if adequate materials are shown to exist.

\footnotetext{
${ }^{3}$ India Constitution, art. 356(1)(a).

${ }^{4}$ India Constitution, art.356, (1)(b).

${ }^{5}$ India Constitution, art.356, (1)(c ).

6 (1994) 3 S.C.C. 1.

${ }^{7}(1977) 3$ S.C.C. 592.

8 (1994) 3 SCC 1 [74] (Sawant, J.).

9 ibid.

${ }^{10}$ (2006) 2 S.C.C. 1.

11 ibid [147] (Sabharwal C J).
} 
In Bommai, the Supreme Court engaged in an objective review of presidential satisfaction in Article 356. Objective review, in its strongest form, seems to encompass four questions - formal, purposive, material and inferential. First, as a matter of form, was the president satisfied? Second, was the satisfaction within the "proper scope” of Article 356? Third, did the president have objective materials on which to make the assessment? Fourth, did the president draw a legitimate inference out of those materials? In other words, only right conclusions based on right materials for right purposes would count as "satisfaction" in Article 356.

As mentioned before, not all judges were on board with the four components. Judges Jeevan Reddy and Agarwal, Sawant and Kuldip Singh, and Ratnavel Pandian in their opinions argued that all four questions were relevant in deciding the proper exercise of satisfaction. ${ }^{12}$ However, Judges Ramaswamy, Ahmadi, and Verma and Dayal together, restricted the scope of judicial review to the formal and purposive only. ${ }^{13}$ The objectivity of materials and the correctness of inferences on which satisfaction is premised upon, they argued, were not amenable to meaningful judicial standards. Presumably, then, for the majority, only certain kinds of materials and inferences counted as valid, as opposed to the minority who chose not to limit president's discretion in these matters. ${ }^{14}$

These disagreements aside, the general conclusion was well received: president's satisfaction in Article 356 is judicially reviewable. And it is fashionable to use this conclusion to exhaust the discussion on the reviewability of presidential satisfaction in Article 123. The argument goes like this. (1) President's satisfaction (e.g. in Article 356) is judicially reviewable. (2) Ordinances (in Article 123) involve president’s satisfaction. (3) Therefore, president's satisfaction in Article 123 is judicial reviewable. This argument is incorrect: the syllogism misleadingly assumes a kind of homogeneity.

When presidents act in pursuance of Article 356, they do so as India's executive head. In Article 123, they (partially) substitute themselves for parliament and act in their original legislative capacity. In Garg v. Union of India, Chief Justice Chandrachud clarified that Article 123 confers "legislative power ... on the President.”" 15 The power to promulgate ordinance is a power to enact primary legislation, and Articles 13 and 367 in their definitions

\footnotetext{
12 Bommai (n 6) [347] (Reddy J.).

13 ibid [201] (Ramaswamy J.).

${ }^{14}$ ibid [35] (Ahmadi J.). See also Soli Sorabjee, 'Decision of the Supreme Court in S. R. Bommai v Union of India’ (1994) 3 Supreme Court Cases (Jour) 1.

15 [1982] 1 SCR 947 [6].
} 
of law clarify this "legislative” label. ${ }^{16} \mathrm{He}$, therefore, concluded that "the Constitution makes no distinction in principle between a law made by the legislature (i.e. an Act of Parliament) and an ordinance issued by the President.” ${ }^{17}$ They are products of legislative power and are subject to similar constitutional limitations. Therefore, the reviewability of presidential satisfaction in Article 123 depends on the principles of judicial review applicable in the context of legislative power. And that explains why a syllogistic reference to Article 356 is a false start, though as we shall see later, the jurisprudence of that provision is not entirely irrelevant to the question at hand.

\section{Text \& Motive: Two Challenges to Overcome}

Because the reviewability of presidential satisfaction in Article 123 depends on the principles of judicial review ordinarily applicable to legislative power, a number of challenges lie ahead. To appreciate them, consider the following set of hypothetical facts. A sudden economic recession has put three of India's leading financial institutions at risk. There is a prospect of bankruptcy, which if it materialises would have a cascading effect on the economy, adding to unemployment and financial losses to millions. Parliament is not in session. The president promulgates The Bank Nationalization Ordinance, 2011 (BNO) with the objective of nationalizing banks at risk to save them from potential bankruptcy. To assume that presidential satisfaction in Article 123 is subject to judicial review would imply that courts may invalidate the BNO on the ground that the president wrongly came to the satisfaction that it was necessary. In other words, the law is unconstitutional because it is unnecessary. That conclusion would be novel, but also analytically challenging for two reasons.

First, Article 245 defines parliament's legislative power: "Subject to the provisions of this Constitution, Parliament may make laws ...” Relying on this provision, the Supreme Court in Gandhi v. Narain, ${ }^{18}$ explained that a law is valid provided Parliament has subjectmatter competence to enact it, and does so without violating provisions of the Constitution. ${ }^{19}$ In State of AP v. McDowell \& Co., ${ }^{20}$ Chief Justice Ahmadi put it more strongly. "A law made by the Parliament can be struck down by Courts on two grounds and two grounds alone (1)

\footnotetext{
${ }^{16}$ See Roy v Union of India AIR 1982 SC 710 [14].

${ }^{17}$ Garg (n 15) [14]. See Nagaraj v State of Andhra Pradesh AIR 1985 SC 551 [31].

${ }^{18}$ AIR 1975 SC 1590.

19 ibid [691].

${ }^{20}$ AIR 1996 SC 1627.
} 
lack of legislative competence and (2) violation of any of the fundamental rights ... or of any other constitutional provision.”21 There is no third ground, he insisted. ${ }^{22}$ But notice the ground for invalidating BNO. It is urged that the law is unconstitutional because it is "unnecessary;" the president wrongly came to the satisfaction that nationalization of financial institutions was "necessary ... to take immediate action.” If accepted, the argument, contrary to previous decisions, would add another ground on which to review the exercise of legislative power.

Second, adding "necessity” as a ground of review would invariably require judges to consider questions of motive. ${ }^{23}$ Why did parliament enact a piece of legislation? Or, with ordinances, why did the president promulgate an ordinance? This leads us to the second hurdle, namely, assessing the constitutionality of legislation on grounds of motive. Parliamentary motives, India’s Supreme Court, has repeatedly held, are irrelevant to the question of constitutionality. In Deo v. State of Orissa, the Court concluded that legislative competence "does not involve any question of bona fides or mala fides on the part of the legislature.” ${ }^{24}$ Because constitutionality is always a question of power, "the motives which impelled it to act are really irrelevant.” This was reiterated in Dutt $v$ Union of India. ${ }^{25}$ The Government had taken over the functioning of a partially publicly funded "non-official, nonpolitical and non-profit organization” through an Act. ${ }^{26}$ When challenged on the ground that it was principally motivated by political malice towards the patrons of the Council, the Court rejected the plea. ${ }^{27}$ "If the legislature is competent to pass a particular law, the motives which impelled it to act are really irrelevant,” Justice Lahoti said. ${ }^{28}$ On the other hand, "if the legislature lacks competency, the question of motive does not arise at all.”

India's position on legislative motive is a straightforward adaptation of English law. In Edinburgh v. Wauchope, ${ }^{29}$ Lord Campbell objected to the idea that courts may enquire into the proceedings of an Act. "All that a Court of Justice can do,” he said, “is to look to the Parliamentary roll." ${ }^{30}$ If an Act is obtained improperly (for reasons of motive, non-

\footnotetext{
21 ibid [45]. (emphasis added)

22 ibid. See State of Karnataka v Union of India and others AIR 1978 SC 68; Nayar v. Union of India AIR 2006 SC 3127.

${ }^{23}$ See Francis Bennion, Bennion on Statutory Interpretation 484-486 (5th edn., LexisNexis 2007).

24 [1954] 1 SCR 1 [9].

${ }^{25}$ AIR 2004 SC 1295 [16].

26 ibid [1].

27 ibid [16].

${ }^{28}$ ibid. See Kerala v. People’s Union for Civil Liberties (2009) 8 SCC 46.

${ }^{29}$ (1842) VIII Clark \& Finnelly 710.

30 ibid 725.
} 
application of mind or otherwise), it is for the legislature to correct it by repealing it. ${ }^{31}$ The position is no different even in cases where a legislature is deceived, and there is proof to that effect: "If a mistake has been made, the legislature alone can correct it." 32 Lord Atkinson repeated that view in Hollinshead v. Hazleton. 33 "The motives which influence the Legislature in passing any particular enactment, or the purposes or objects it desired to effect, can only be legitimately ascertained from the language of the enactment," he said. ${ }^{34}$ In other words, legislative motive, if any, must be located in the words of an Act.

The Indian and English positions, however, are in contrast to the US developments in this matter. In a recent article, ${ }^{35}$ Professor Caleb Nelson argues that the use of motive in assessing constitutionality of legislation in the US has gone through four phases. The first period stretched from the early years of the republic till 1870s, ${ }^{36}$ second from 1870 s to 1930s, ${ }^{37}$ third from 1930 s to 1970 s $^{38}$ and finally, from 1970 s to the present. ${ }^{39}$ While acknowledging purpose based limitations of constitutional provisions, the first phase, Nelson argues, was characterized by a refusal to inquire into legislative motives. ${ }^{40}$ And though the antebellum courts were willing to set aside statutes that either candidly acknowledged their unconstitutional purposes or otherwise foreclosed any innocent explanation by their very language, most statutes that said nothing about their goals were effectively insulated from purpose-based judicial review. ${ }^{41}$

In the second phase, judges were willing to draw upon materials other than the express words of a statute in deciding if it was vitiated by an impermissible purpose, including public facts of the sort eligible for judicial notice. ${ }^{42}$ But they also began to tinker with the applicable standard of proof. Instead of giving the legislature every conceivable benefit of doubt, they were willing to impute impermissible purposes to statute even in cases where alternate explanations were possible. ${ }^{43}$ The third phase saw a measured return to the jurisprudence of antebellum courts. Chief Justice Warren wrote the seminal opinion of this

\footnotetext{
${ }^{31}$ Lee v Bude (1870-71) L.R. 6 C.P. 576, 582 (Willes J.)

${ }^{32}$ Labrador Co. v. The Queen [1893] A.C. 104, 123 (Hannen LJ). See British Railways Board Appellants v Pickin [1974] A.C. 765.

33 [1916] 1 A.C. 428.

34 ibid, 438. See Tukino v. Aotea District Maori Land Board [1941] A.C. 308. See also HalsBury's LAWS OF ENGLAND, Vol. 36 para. 560 (3rd ed.,1961).

${ }^{35}$ Caleb Nelson, 'Judicial Review of Legislative Purpose’ 83 New York University L Rev 1784 (2008).

36 ibid 1795-1811.

37 ibid 1812-1834.

38 ibid 1835-1849.

39 ibid 1849-1858.

${ }^{40}$ ibid 1796.

41 ibid 1803.

42 ibid 1813.

${ }^{43}$ ibid.
} 
period in United States $v$ O'Brien, ${ }^{44}$ one that effectively shut the door on internal legislative deliberations as a guide to Congress's impermissible motivations. Equally, courts were inclined to return to the earlier standard of proof that was willing to grant the legislature widest possible benefit of doubt in matters of motives. ${ }^{45}$

But things have once again changed from the 1970s, Nelson says. Judge Powell's majority opinion in Village of Arlington Heights v Metropolitan Housing Development Corporation $^{46}$ is instructive of how far courts have come in this regard. In determining invidious discriminatory purposes, judges, he said, may consider the "sequence of events leading up to the challenged decisions," the "legislative or administrative history” and in extraordinary cases, may even summon individual legislators "to testify concerning the purpose of the official action." 47 The opinion's influence is hard to overestimate. Increasingly, vast swathes of doctrinal areas have been taken over by legislative motive inquiry. ${ }^{48}$ Though the proper method of accounting for conflicting motives, or aggregating them remains a challenge, under current law, legislative motive is a relevant object of study in the US, and an acceptable basis on which to invalidate legislation.

So how would our SBO fare in the three systems? Irrespective of the motives that may have animated the Ordinance, given current law, presidential satisfaction would not be reviewed in India or England. Nor would it be reviewed in Nelson's first and third period. Depending on the motives alleged, and the kind of evidence adduced to substantiate that, the argument might receive a sympathetic hearing in the second and fourth period. But the success of motive arguments is hard to predict; there is thus far no case where a statute has been successfully challenged solely on grounds of impermissible motives.

To summarize then, legislative power in India is subject to two conditions only parliamentary motives not being one of them. And because the Supreme Court has tied Acts and ordinances to the same string of legislative power, expanding judicial review in one case (say ordinances) leads to an expansion in the other (Acts). If president's legislative satisfaction in Article 123 is to be subject to judicial review, we will need a different analysis by which to account for it.

\footnotetext{
44391 U.S. 367 (1968). See Barenblatt v. US 360 U.S. 109(1959).

${ }^{45}$ Nelson (n 35) 1841.

46429 U.S. 252 (1977).

47 ibid 267-68.

48 See Nixon v. Adm'r of Gen. Servs., 433 U.S. 425 (1977); DiMa Corp. v. Town of Hallie, 185 F.3d 823 (7th Cir. 1999); Smithfield Foods, Inc. v. Miller, 367 F.3d 1061 (8th Cir. 2004); Allstate Ins. Co. v. Abbott, 495 F.3d 151 (5th Cir. 2007).
} 


\section{Three Strategies for Judicial Review}

Consider Article 123(1): "If at any time, except when both Houses of Parliament are in session, the President is satisfied that circumstances exist which render it necessary for him to take immediate action, he may promulgate such Ordinances as the circumstances appear to him to require.” Three elements make up Article 123: (a) the exercise of original legislative power (b) by the executive (c) at its discretion. And this exercise of legislative power is based on three conditions: (a) both Houses are not in session (b) the president is satisfied of some legislative emergency and (c) that immediate action is necessary. In other words, president's legislative power is conditional; three conditions must be satisfied prior to its use. But this conditional exercise of legislative power in Article 123 is different from Article 245 that defines parliament's legislative power: "Subject to the provisions of this Constitution, Parliament may make laws for ... India.” The latter, as should be obvious, is subject to one condition only, namely that the exercise of such legislative power be "subject to the provisions of the Constitution.”

Because both presidential and parliamentary legislative powers are conditional, it would be misleading to emphasise "conditionality" as the distinguishing feature of the former. Therefore, recasting president's legislative powers as circumstantially conditional may be a more apt description. That is to say, while Article 123 specifies the particular circumstances in which president's legislative power may be invoked, Article 245 is silent on the matter; it leaves it to the discretion of parliament. With this difference in mind, we may turn to three competing strategies for judicial review.

The first strategy might be to equate judicial review of Acts (i.e. ordinary legislative power) with those of ordinances (i.e. circumstantially conditional legislative power) while maintaining that both are reviewable on identical grounds. We know Acts in India cannot be reviewed based on, say, motive. Therefore, ordinances too cannot be reviewed based on motive. Or, we know Parliament's decision to enact a piece of legislation cannot be reviewed. Therefore, a President's decision to promulgate an ordinance cannot likewise be reviewed. The strategy requires an emphasis on the legislative nature of both powers. That they are 
prefaced by different conditions is relatively immaterial. We may refer to this as the negative approach to judicial review of presidential satisfaction.

The second strategy might be to disassociate the review of Acts from ordinances, by emphasizing the circumstantial conditions that distinguish the former. Here differences are highlighted rather than underplayed. And it may be put in the following form. While both ordinances and Acts are products of legislative power, they are prefaced by different conditions, thus making them distinct categories of legislative power. Therefore, ordinances may be reviewed on grounds normally inapplicable to legislation. That both share the narration of legislative power is relatively immaterial here. We may refer to this as an intermediate approach to judicial review.

The third strategy might be to equate Acts with ordinances, while arguing that both should be reviewed on expanded grounds. The argument is a two-step process and may be put in the following form. Thus far, courts have erred in refusing to review the constitutionality of Acts based on, say, legislative motive. If unjustifiably vitiated by animus towards a person or group, a law should be invalidated on that ground. And for that reason, an ordinance too should be invalidated if presidential satisfaction in promulgating it is vitiated by mala fide. The third strategy then is a hybrid: it equates ordinances with Acts (as in the first instance) but argues in favour of judicial review (as in the second instance). The point here is to narrow the distinction between executive power and legislative power, and to make the latter reviewable on grounds ordinarily reserved for the former. We may refer to this as the positive approach to judicial review of presidential satisfaction.

Of the three, the first strategy is evidently the most conservative. It leaves currently applicable principles of judicial review untouched while incorporating ordinances into its fold. Conversely, the third strategy is the most radical: it seeks to widen the scope of judicial review by adding new grounds. To adopt this strategy is to buy into the US position on legislative motive, particularly as understood in the fourth phase. The second strategy, on this consideration, is a median position: applicable principles are left untouched while expelling ordinances from its purview. But it has the effect of impliedly relying on a category of legislative power - call it an "intermediate legislative power" - that is neither fully executive (e.g. Article 356), nor fully legislative (e.g. Article 245). It is mostly, though not entirely, legislative. And it is "intermediate” because of its office, nature and scope. Officially, it is exercised by the executive, non-deliberative and transient in nature and limited in its scope. Intermediate legislative power cannot do everything that ordinary legislative power can. With 
this background, we may now turn to the leading decisions to understand the ways in which these strategies for judicial review have been rejected or applied in practice.

India's Supreme Court has mostly remained anchored to the first strategy, i.e. the negative approach to judicial review. Two decisions are paradigmatic of this approach. In Nagaraj v State of Andhra Pradesh, ${ }^{49}$ Chief Justice Chandrachud stated his position: an ordinance could not "be invalidated on the ground of non-application of mind." 50 The power to issue an ordinance was "not an executive power but [a] power of the executive to legislate." 51 And because "transferred malice," was unknown to the field of legislation, an ordinance could not be invalidated on the ground of malafide intent either. This view was repeated in Reddy $v$ State of Andhra Pradesh. ${ }^{52}$ Armed with an elaborate discussion on the "legislative" nature of the power involved, ${ }^{53}$ the Court parroted the obvious conclusion: "While the courts can declare a statute unconstitutional when it transgresses constitutional limits, they are precluded from inquiring into the propriety of the exercise of the legislative power." 54

The argumentative structure of these decisions is consistent with the negative approach outlined earlier. The applicability of judicial review in both cases was worked out with an exclusive focus on the legislative nature of the power in Article 123. That it is prefaced by distinct conditions did not matter. For the Supreme Court, then, ordinances are exactly like legislation and, therefore, subject to identical limitations. The immediate effect of this equivalence is to validate every act of presidential satisfaction. As long as parliament is not in session, presidents may, whenever, howsoever, and for whatever reasons come to the satisfaction that it is necessary to take immediate action. They may even purposefully create a situation of legislative emergency by dissolving a House in session to promulgate an Ordinance, and, that too, High Courts say, cannot be judicially reviewed. ${ }^{55}$ Presidential satisfaction in Article 123, in other words, is limitless. This thoroughly subjective approach to presidential satisfaction pursuant to legislative powers is in striking contrast to the Court's objective approach to presidential satisfaction pursuant to executive powers discussed earlier.

\footnotetext{
${ }^{49}$ AIR 1985 SC 551.

50 ibid [31]. See Agarwal v State of UP AIR 1956 All 557.

51 ibid [31].

${ }^{52}$ AIR 1985 SC 724.

${ }^{53}$ Garg (n 15) [6] (Bhagwati J)

${ }^{54}$ Nagaraj (n 49) [14].

${ }^{55}$ In Re K. Veerabhadrayya AIR 1950 Mad 243.
} 
Though the Supreme Court has remained strongly wedded to the first strategy, Judge Sujata Manohar in her opinion in Singh $v$ State of Bihar ${ }^{56}$ seems to have adopted the intermediate approach. In December 1989, the State of Bihar took over the management and control of non-governmental schools through an ordinance, re-promulgating the same seven times till April 1992. All ordinances including the original one were declared invalid. Judge Manohar began by dissociating ordinances from Acts, focussing on the conditions that make the former distinct. The power to promulgate ordinances has certain safeguards, she said. They are "not a substitute for regular legislation," of "limited duration" and must be laid before the Assembly when it reassembles. ${ }^{57}$ With the exceptions in mind, she turned to the question of judicial review. The State gave no justifications for the immediate action. Nor did it have any "intention of placing any Ordinance before the legislature," she claimed. ${ }^{58}$ Repeatedly repromulgations were a ploy to make legislative scrutiny impossible. The Governor's satisfaction, therefore, she concluded, was fraudulent.

This was a remarkable finding: the president or governor's legislative satisfaction had never been declared invalid previously. But she was careful to limit her novel extensions to presidential legislation only. There was no suggestion to review parliamentary legislation (i.e. Article 245) on similar grounds. In that sense, her decision impliedly relied on a category of intermediate legislative power suggested earlier, one that is neither fully executive nor legislative.

The only other judicial application of the intermediate approach came from the Karnataka High Court in Hasanabha v. State of Karnataka. ${ }^{59}$ In this case, an ordinance altering an electoral verdict was under challenge. Elections to a local body were held in 1997. The ruling party did not secure a majority and the State Government introduced an ordinance authorizing the appointment of 3 nominated members to every elected committee "to hold office at the pleasure of the Government." That effectively tilted the verdict in favour of the ruling party.

The Governor's decision to promulgate the ordinance after the electoral verdict, petitioners argued, bristled with mala fides. To them, it was designed to achieve ulterior ends rather than remedy any "real” situation of legislative emergency. Judge Saldanha agreed. To him, the ordinance "was hopelessly ill-timed," and the mala fide argument had merit. ${ }^{60}$ In

\footnotetext{
${ }^{56}$ AIR 1998 SC 2288.

57 ibid [21].

58 ibid [25].

${ }^{59}$ AIR 1998 Kant. 91.

60 ibid [7].
} 
coming to that conclusion, he, like the judges in Nelson's second period in the US, was unwilling to grant the governor every benefit of doubt. Describing the Ordinance as "a total and complete sabotage," ${ }^{61}$ he rejected the State's claim that it was motivated by a desire to provide representation to those belonging "to weaker sections and women.” That, to him, was nothing more than an afterthought. ${ }^{62}$ Once again, like the judges in Nelson's second and fourth period, he was willing to draw upon materials other than the express words of the Ordinance to assess its underlying motives. The Chief Minister's admission in the State Legislature that the Ordinance was necessary “for purposes of furthering the ruling party’s interest," he said, was a testimony to the Government's real motives. ${ }^{63}$ And for those reasons, the Ordinance was invalid; the Governor, he claimed, wrongly came to the satisfaction that it was necessary.

This was a clear case of invalidation on grounds of motive; the law was illegal not for what it said, but when - and the purposes for which - it was said. No provisions in the Constitution were found to have been contravened. Rather, Judge Saldanha pointed out that the Government had ample opportunity to alter the composition prior to the elections, implying that if it had been done at a different point in time, the Ordinance may have been valid. And like Judge Manohar in Singh, he stayed firmly anchored to the intermediate approach. The lack of democratic debate and the "unbridled power to promulgate provision [having] the effect of law" made it necessary to scrutinize ordinances with a "higher degree of care and caution.” ${ }^{4}$ This is particularly so when ordinances are challenged on grounds of mala fides. In such cases, it is important for the court to "examine it perhaps with a higher degree of meticulousness," he said. ${ }^{65}$ Both Singh and Hasanabha, then, are classic applications of the second strategy. They play on the differences between Acts and ordinances while arguing that only the latter is subject to judicial review on grounds of motive, bad faith or non-applicability of mind. But it should be parenthetically mentioned that Hasanabha was promptly overturned on appeal. In a terse opinion, Chief Justice Sethi reiterated the standard "principle of interpretation of constitutional law that the legislature, as a body, cannot be accused of passing the law on the ground of mala fides." ${ }^{\circ 6}$ On the view that the decision was “a mistake of law,” Saldanha’s opinion was overturned. ${ }^{67}$

\footnotetext{
${ }^{61}$ ibid [6].

62 ibid [7].

63 ibid [5].

${ }^{64}$ ibid [10].

${ }^{65}$ ibid (emphasis added).

${ }^{66}$ State of Karnataka v B. A. Hasanabha AIR 1998 Kant. 210 [5].

67 ibid [6].
} 
Some academic commentators have impliedly warmed up to the intermediate approach. Both H. M. Seervai and M. P. Jain, India's leading public law authors, rely on it. ${ }^{68}$ Sympathetic to the necessity of judicial review, both present their analysis by disassociating ordinances from Acts. Seervai, for example, emphasises the executive’s discretionary involvement with ordinances while underplaying its legislative character. And because his arguments are built around that emphasis, he is conveniently able to exclude Acts from its purview: "No law enacted by Parliament can be set aside on the ground that it was passed mala fide." 69 Jain takes a similar position. He is critical Reddy, arguing that the Court seemed "to have gone too far in immunizing an ordinance from judicial review."70 It does not seem correct, Jain says, "to treat an ordinance on all fours with an Act passed by Parliament."71 Therefore, challenging the executive decision on the ground of mala fide "should always remain a possibility.” For that reason, he commends Judge Saldanha in Hasanabha, and is critical of the appellate court that overturned it. But these arguments notwithstanding, the intermediate approach still remains at the margins of public law in India.

And if the second strategy is that the margins, the third one - the positive approach is still further out. It has barely registered in India. With the possible exception of Judge Ray's minority opinion in Cooper $v$ Union of India, ${ }^{72}$ the idea has never been judicially proposed or upheld. In Cooper, the constitutional validity of the Banking Companies (Acquisition and Transfer of Undertakings) Ordinance, 1969 was challenged on the ground that there was no need for immediate action and that the president wrongly claim to the conclusion that an ordinance was necessary. In his dissenting opinion, Judge Ray (as he was then) concluded that establishing bad faith or corrupt motive was the only way to challenge presidential satisfaction. Bad faith, he added, "will destroy any action."73 If by "any action” he intended to include both executive and legislative actions, then Ray is squarely in sync with the third strategy. It would imply that Acts (and, therefore, ordinances too) may be invalidated on the ground that it was motivated by animus towards a person or group.

India's disinterest in the positive approach is in contrast to state of art in the US. Today, motive arguments are central to many areas of constitutional law, and especially so

\footnotetext{
${ }^{68}$ H. M. Seervai, Constitutional Law of India Vol. 3, 2566-7 (4th edn., Universal Law 2007); M. P. Jain, Indian Constitutional Law 174-5 (5th edn., LexisNexis 2009).

${ }^{69}$ Seervai (n 68) 2566.

${ }^{70}$ Jain (n 68) 175.

${ }^{71}$ ibid.

${ }^{72}$ AIR 1970 SC 564.

${ }^{73}$ ibid [244] (emphasis added).
} 
with regards to statutes alleged to disadvantage African-Americans, ${ }^{74}$ restrict unpopular speech or religion, ${ }^{75}$ or punish a disfavoured individuals. ${ }^{76}$ While differences persist in specific doctrinal areas, the very plausibility of making legislative power subject to mala fide inquiry is no longer in doubt. And it may be profitable to briefly consider the arguments for doing so here.

Much of the analytical foundation for motive analysis was initially offered by Professor John Ely in 1970 and later reworked by Professor Paul Brest in $1971 .{ }^{77}$ Brest argued that motive inquiry, properly understood, "focuses on the process by which the rule or decision was made; it asks what criteria or objectives the decision-maker took into account.”78 The substantive decision is not of concern; rather the inquiry merely points out considerations that cannot be taken into account in enacting a given legislation. ${ }^{79}$ And while discerning the sole or dominant reason underlying the choices of a group of legislators is challenging, such rigorous proof is not essential to motive analysis. It would suffice "to demonstrate that illicit motivation played a non-trivial part in the decision-making process, so that it might have affected the outcome." 80 This process of teasing out legislators' motives is about drawing inferences based on legislators' actions “viewed in the context of antecedent and concurrent events and situations" - a process not unlike inferences in other areas of law. Amongst others, the content of the law, its timing in juxtaposition with some prior event or sequence of events and maker's statements about the purpose of the law or rule are acceptable ways of reading the mind. ${ }^{81}$

This analytical structure is clearly visible in Hasanabha. Knowingly or otherwise, Judge Saldanha adopted Brest's arguments to partially defend motive analysis in India. But unlike Brest, he limited it to ordinances only. Nothing in his decision suggested that Acts too may be reviewed on this basis. That is unsurprising because fully appropriating Brest in India

\footnotetext{
${ }^{74}$ See Hunter v. Underwood, 471 U.S. 222 (1985); Perry, 'The Disproportionate Impact Theory of Racial Discrimination’ 125 Uni. Pennsylvania L Rev 540 (1977).

75 See Lemon v. Kurtzman, 403 U.S. 602 (1971); Church of the Lukumi Babalu Aye v. City of Hialeah, 508 U.S. 520 (1993).

76 See Nixon v. Adm'r of Gen. Servs., 433 U.S. 425 (1977).

77 John Hart Ely, 'Legislative and Administrative Motivation in Constitutional Law' 79 Yale L J 1205 (1970); Paul Brest, 'Palmer v. Thompson: An Approach to the Problem of Unconstitutional Legislative Motive' 1971 Supreme Court Rev 95. See also Eisenburg, 'Disproportionate Impact and Illicit Motive: Theories of Constitutional Adjudication' 52 New York Uni L Rev 36 (1977); Clark, 'Legislative Motivation and Fundamental Rights in Constitutional Law’ 15 San Diego L Rev. 953 (1978); Elena Kagan, 'Private Speech, Public Purpose: The Role of Governmental Motive in First Amendment Doctrine’ 63 Uni Chicago L Rev 413 (1996).

${ }^{78}$ Brest (n 77) 115.

${ }^{79}$ ibid.

80 ibid.

${ }^{81}$ ibid 124.
} 
is difficult. The central argument for judicial invalidation of a law on the ground of illicit motive, as Brest admits, hinges on the idea that "governments are constitutionally prohibited from pursuing certain objectives ...”82 The Constitution, in other words, imposes purposebased limitations on the legislature's power to enact certain legislation. That is to say, why a legislature enacted a law matters as much as what it has enacted. But this interpretation of legislative power has never been accepted in India. Starting with Deo, the Supreme Court has struck to the view that legislative competence is exclusively a question of power: "If the legislature is competent to pass a particular law, the motives which impelled it to act are really irrelevant.” Only "what” matters; “why” is irrelevant. Until it can be shown that India’s Constitution imposes limits on the reasons for which parliament may act, fully appropriating Brest's analysis is analytically challenging.

Now that we have three alternatives through which to address judicial review in Article 123, which one should we adopt? In the next section, I will argue that this question cannot be addressed by simply referring to the relevant text for it is "agnostic" on the point. That choice must necessarily depend on something outside of the text - something external to it.

\section{President's Legislative Power in Perspective}

In 1975, Article 123 was amended to including the following: "Notwithstanding anything in this Constitution, the satisfaction of the President mentioned in Clause (1) shall be final and conclusive and shall not be questioned in any Court on any ground.” 83 Three years later, the amendment was deleted. The provision, both in its original and current form, says nothing about judicial review. In this respect, Article 123 is semantically agnostic. Therefore, the validity of the competing strategies cannot be decided simply by referring to the text.

For this reason, arguments proclaiming to derive positions on judicial review from the provision itself, as Seervai and Jain purport to do, are not worth taking seriously. They reflect little more than the authors’ personal preferences. Seervai, for example, argues that "discretionary power conferred on the executive either by the Constitution or by a law, and dependent on the existence of a condition precedent is subject to the jurisdiction of the Courts ...”4 By implication, president’s satisfaction in Article 123, he concludes is reviewable. But

\footnotetext{
82 ibid 116. (emphasis added)

83 See 38th Constitution (Amendment) Act, 1975, s 2. (India)

${ }^{84}$ Seervai (n 68) Vol 2, 1130.
} 
that claim regarding the reviewability of discretionary power with condition precedents is his understanding of discretionary power; Article 123 says nothing about it. Elsewhere, he argues that “the Constitution puts limitations on the President's powers under Article 123 and if the powers are transgressed, e.g., by the promulgation of an Ordinance mala fide, the rights of the people are affected illegally." 85 This is incorrect. Nothing in the Constitution limits the president's power to promulgate. If limits exist, they do so because of Seervai's preference for it. Secondly, the reference to "validity" assumes the existence of some higher principle that can help us arbitrate between the competing strategies. That is unlikely. ${ }^{86}$ To the extent that all three strategies satisfy (conventional?) conditions for valid and sound arguments, they are likely equally valid. If that is so, judicial review of presidential satisfaction in Article 123 will largely depend on the strategy one adopts, i.e. on what one chooses to emphasise (or deemphasise) in the text. In other words, because the text runs out at this point, effectively the reader must decide the strategy to adopt.

To say that the choice of strategy is textually arbitrary is not to suggest that its validity cannot be judged from any other vantage, if somewhat "external," point. The history of potential misuse and the appropriate level of discretion is one starting point. The question of judicial review, in large measure, is a question of discretion. Should the executive have wide discretion in promulgating ordinances? Or should that discretion be limited? Depending on one's view of the appropriate level of discretion, some strategies will make more sense than others. The second or third strategy is unambiguously better for those with a preference limiting the executive's discretion. Unsurprisingly, Seervai, in making his case for judicial review in Article 123 quickly took refuge in what he saw as a history of abuse. ${ }^{87} \mathrm{He}$ discussed at length research in the field that pointed to the executive's frequent use of ordinances, often times, with the intent of undermining the legislative process. ${ }^{88}$ Later, he chided Chief Justice Chandrachud for his refusal to adjudicate the question of judicial review in Roy v Union of India with a degree of finality. ${ }^{89}$ The government, he pointed out, "had promulgated about 200 Ordinances between 1960 and 1980 of which 19 had been passed in 1980." 90 Having regard to this frequent use, "for a court to allow a large section of our people's rights to be affected by what may turn out to be illegal executive action without redress,” he thought, could “only be described as an unjustified abdication of judicial

\footnotetext{
85 ibid 1116.

${ }^{86}$ See Duncan Kennedy, Legal Reasoning: Collected Essays 87-152 (The Davies Group 2008).

${ }^{87}$ Seervai (n 68) 2567-71.

${ }^{88}$ On research in this matter, see Wadhwa (n 1).

${ }^{89}$ Seervai (n 68) Vol 2, 1117.

${ }^{90} \mathrm{ibid}$.
} 
power." ${ }^{11}$ Jain, too, justifies his case for judicial review as a way of deterring executive excesses in future. ${ }^{92}$ The possibility of review, he argues, will act as an effective check against executive excesses.

As these arguments readily suggest, a sympathetic reading of judicial review is largely grounded in the belief that the power to promulgate ordinances has been misused, or in the fear that it will be. For Seervai and Jain, misuse, as fact or likelihood, serves as a metaanvil through which to make sense of the competing strategies. To them, the "correct" strategy is one that does not preclude a judicial assessment of legislative necessity. And because they prefer to limit the scope of this assessment to ordinances only, the intermediate approach is their obvious ally. To be sure, this manner of accounting for the question of judicial review is not unreasonable. But doing so, at least requires an acknowledgement that it is a product of something outside of, or external to, Article 123.

If we are to use the anvil of "misuse" to make president's satisfaction in Article 123 judicially reviewable, we need a fuller account of intermediate legislative power and the ways in which it is distinct ordinary legislative power. Legislative power, I would argue, is intermediate when it is exercised by the executive in its original capacity. Executive bodies including the Cabinet frequently make laws that are delegated in nature; their authority rests on parliamentary approval. With intermediate legislative power, executive has the power to enact primary legislation; the initial exercise of the power is not dependent on anything else.

While any numbers of differences between intermediate and original legislative power may be constitutionally designed, its Indian expression in Article 123, I believe, has the following features. First, its initial exercise is non-deliberative. Parliamentary scrutiny, if any, occurs post-enactment. Second, given the history of misuse, president's assessment of legislative necessity in Article 123, unlike parliament's similar assessment, is potentially open to judicial review. Third, as product of intermediate legislative power, ordinances are transient. While the duration of ordinances is not spelled out directly, their permanence is clearly dependent on future legislative approval. Fourth, if ordinances are not enacted into legislation through normal procedure, they lapse. In such cases, legal effects of ordinances get wiped out retrospectively; it is as if the ordinances never existed. ${ }^{93}$ Fifth, while ordinances and Acts have similar subject-matter scope, some additional limitations apply to ordinances with respect to retrospective and prospective provisions. None of these, however,

\footnotetext{
91 ibid.

92 ibid.

${ }^{93} \operatorname{Dam}(\mathrm{n} 1)$ 145-148.
} 
are necessary or sufficient features of intermediate legislative power. These are merely its Indian expression, and other jurisdictions may define it differently. For example, it is conceivable that intermediate legislative power elsewhere may enforce a strict period of duration, impose subject-matter limits, or guarantee legal validity to actions taking under a lapsed ordinance.

And finally, it is worth noting that two aspects of intermediate legislative power in its Indian expression may be judicial reviewed. In the first instance, judicial review may pertain to the president's substantive satisfaction. Hasanabha is a classic example. There Judge Saldanha reviewed the governor's substantive satisfaction that an ordinance amending the results of a local election was necessary. His arguments and reasoning were about the subject-matter of the law, its implied effect of undoing the electoral verdict and the motives that may have animated the decision to promulgate that Ordinance. But judicial review may also focus on the president's procedural satisfaction. Krishna Kumar is a good example of this. There, Judge Manohar zoomed in on the government's apparent disinterest in completing the legalization process. Because an ordinance in Article 123 is transient and requires parliamentary approval in future to acquire permanence, promulgating it may be procedurally malafide if the president has no intention of seeking approval in future. Without that intent, ordinances can become a cynical practice designed to circumvent the ordinary legislative process and the accountability that comes with it. And Judge Manohar found the State wanting in this regard: there was "no intention of placing any Ordinance before the legislature.”94 Unlike Hasanabha, the focus in Krishna Kumar is not on the governor's substantive satisfaction regarding the law. Rather, Manohar focused on the procedural disinterest and the government's apparent intent in undermining the ordinary legislative process. Note that this procedural review - understood as the president's intention of seeking future parliamentary approval - is unique to intermediate legislative power. For obvious reasons it does not apply to ordinary legislative power.

What about BNO 2011 then? If understood through the prism of intermediate legislative power, presidential satisfaction regarding that ordinance, contrary to the current law in India, should be judicially reviewed. If challenged on the ground that the proposed nationalization was motivated by a desire to protect the pecuniary interests of ministers rather than remedy any "real” situation of financial emergency, it would fall on judges to assess that claim. Like in Bommai, judges may be required to address all four components of judicial

\footnotetext{
${ }^{94}$ Singh (n 56) [25].
} 
review discussed earlier - formal, purposive, material and inferential. After all, a decision about the real nature of a financial emergency cannot be meaningfully made without reviewing materials on which the president relied upon, or without knowledge of the inferences she drew from them. For this reason, contrary to the minority view in Bommai, judicial review in Article 123 must include all four components. Limiting its scope to the formal and purposive, as the Bommai minority chose to do with regards to Article 356, is not a coherent option.

\section{Conclusion}

Ordinances are an anomalous feature of India's parliamentary system. The president, acting through the Union Cabinet, has original legislative power to enact legislation with the same force and effect as Acts. And their frequent use (and potential misuse) makes the question of judicial review particularly compelling. The case for judicial review of presidential satisfaction cannot rest on Article 123 for it is agnostic in this regard. Nor will a straightforward application of current principles applicable in associated areas of presidential satisfaction achieve that objective. Rather, the best case for judicial review depends on recognizing a category of intermediate legislative power - one that neither fully executive nor legislative, but with important characteristics of both. Fostered out of a desire to constrain potential misuse, the category provides a comfortable mean; it excludes the possibility of absolute immunity without radically reorganizing applicable principles of judicial review. And the success of constraining president's promulgative boundaries in India may crucially hinge on how well we understand this concept of intermediate power, and its mechanics in practice. 